\title{
A CONTRIBUIÇÃo DE FranÇOIS LAURENT ÀS DOUTRINAS DE DIREITO INTERNACIONAL PRIVADO DO SÉCULO XIX ${ }^{1}$ NATUREZA E FONTES DO DIREITO INTERNACIONAL PRIVADO
}

\section{BETWEEN UNIVERSALISM AND NATIONALISM. THE CONTRIBUTION OF FRANÇOIS LAURENT TO THE PRIVATE INTERNATIONAL LAW DOCTRINES IN THE NINETEENTH CENTURY}

\author{
Elisabeth Bruyère ${ }^{2}$ \\ ORCID: 0000-0002-2933-7462
}

\begin{abstract}
Resumo
No auge de sua carreira, o jurisconsulto, historiador e filantropo François Laurent escreveu uma enorme obra de oito volumes com o objetivo de fornecer uma resposta à questão do conflito de leis. Ao fazer isso, ele deseja inspirar diplomatas e legisladores. Como membro do Instituto de Direito Internacional, ele se correspondeu com muitos jurisconsultos europeus, incluindo Pasquale Stanislao Mancini e Johann Caspar Bluntschli. Com sua teoria personalista entre universalismo e nacionalismo, François Laurent oferece um poderoso testemunho da persistência da lei da natureza no final do século XIX
\end{abstract}

Palavras-chave: Direito internacional privado. Conflito de leis. Nacionalismo. Direito natural.

\begin{abstract}
At the height of his career, jurisconsult, historian and philanthropist François Laurent wrote a massive eight-volume work aimed at providing an answer to the question of conflict of laws. In so doing, he wishes to inspire diplomats and legislators. As a member of the Institute of International Law, he corresponded with many European jurisconsults, including Pasquale Stanislao Mancini and Johann Caspar Bluntschli. With his personalist theory between universalism and nationalism, François Laurent delivers a powerful testimony of the persistence of nature law at the end of the 19 th century.

Keywords: International private law. Conflict of laws. Nationalism. Nature law,
\end{abstract}

\footnotetext{
1 "François Laurent et les doctrines $d u$ droit international privé du XIXe siècle", tradução da língua francesa por Arno Dal Ri Jr.

2 Doutora em Direito pela Universidade de Gent, na Bélgica. Contato: elibruyere@ gmail.com

DOI: https://doi.org/10.46699/rduno.v3i4.6031 | Edição Vol. 3, Núm. 4, 2020. 


\section{INTRODUÇÃO}

Em uma obra que publica entre 1880 e 1881, o professor, pensador e político belga François Laurent (1810-1887) atualiza uma teoria de direito internacional privado extremamente desenvolvida. Intitulada Droit civil international $^{3}$, era abrigada em oito volumes e antecipava a reforma do Código Civil belga ${ }^{4}$, que o autor concomitantemente preparava para o ministro da justiça da Bélgica, Jules Bara.

Para desenvolver sua teoria, Laurent se apoiava em um número importante de fontes doutrinárias clássicas e contemporâneas, mas igualmente jurisprudenciais. Quanto a sua interpretação do Código Napoleônico, considerava que esse somente retomava as teorias tradicionais, confirmando os sistemas do Antigo Regime. Laurent desenvolveu, então, o conflito de leis de lege lata com o auxílio de antigas fontes, autoridades da doutrina, como por, exemplo, Jacques Cujas, Charles Dumoulin, Jean Domat, François Bourjon, Jean Bouhier, Louis Boullenois, Nicolas de Bourgoigne, Guy Coquille, Paul Voet e Johannes Voet, Bertrand d'Argentré, Johann Nikolaus Hert, Ulrich Hubert e Louis Froland.

De lege ferenda, método que elaborou, consistia em buscar o fundamento de cada instituição jurídica ou disposição tentando entender se era uma norma real ou pessoal. Para desenvolver seu novo sistema, Laurent passou um pente fino nas teorias dos autores contemporâneos que tinham se dedicado à difícil matéria do direito internacional privado. Entre esses, encontram-se Pasquale Stanislao Mancini e Friedrich Carl von Savigny, assim como constam numerosas referências a Tobias Asser, Charles Brocher, Charles Demangeat, Pietro Esperson, Pasquale Fiore, Jean-Jacques Foelix, Carl Mittermaier, Joseph Story, Carl Ludwig von Bar, Henry Wheaton e Carl Georg von Wächter. Encontram-se também menções a Nicola Rocco, autor de um tratado sobre o conflito de leis no Reino das Duas Sicílias que inspirou muito Mancini. Para apoiar suas teorias, Laurent também analisou numerosos acórdãos e sentenças belgas, francesas e estrangeiras para criticá-los ou aplaudi-los. Através da apresentação de diferentes legislações de direito civil europeias, mas também norte-americanas, o Droit civil international constituía, ainda, um formidável trabalho de direito privado comparado.

Nesse artigo será examinada a perspectiva que François Laurent tinha do direito internacional privado e a maneira com a qual desenvolve aspectos da doutrina italiana, mais

\footnotetext{
${ }^{3}$ LAURENT, François. Droit civil international. 8 t. Bruxelles: Bruylant-Christophe, 1880-1881.

${ }^{4}$ LAURENT, François. Avant-Projet de révision du code civil. 6 t. Bruxelles: Bruylant-Christophe, 1882-1885.

DOI: https://doi.org/10.46699/rduno.v3i4.6031 | Edição Vol. 3, Núm. 4, 2020. 
precisamente, o personalismo de Pasquale Stanislao Mancini. Por primeiro serão expostos os modos como Laurent contemplava a natureza e as fontes do direito internacional privado. A seguir, serão examinados os princípios fundamentais que regem o sistema por ele elaborado. Enfim, abordaremos os destinatários de seu sistema.

\section{NATUREZA E FONTES DO DIREITO INTERNACIONAL PRIVADO}

\section{Na linha da doutrina italiana}

O interesse de Laurent pelo direito internacional privado não era novo. Já em 1869, antes mesmo de começar a redigir seus Principes de droit civil, publicou um projeto de direito internacional privado no primeiro número da Revue de droit international et de législation comparée, dirigida por Gustave Rolin-Jaequemyns, Tobias Asser e John Westlake, em que defendia o princípio da personalidade das leis ${ }^{5}$. Pietro Esperson comentou esse projeto no ano seguinte, no âmbito da sua obra Movimento giuridico in Italia e nel Belgio sul Diritto internazionale privato ${ }^{6}$, aproximando as ideias de Laurent com aquelas do novo Código Civil italiano de 1865.

A Comissão especial para o direito e o processo civis ${ }^{7}$ do Institut de droit international, na espera de um estudo especial de Laurent na matéria, adiou por um ou dois anos a entrega de suas conclusões, mas teve finalmente de resolver, não tendo recebido do jurisconsulto de Gante, ir a diante sem a participação dele ${ }^{8}$. Também Laurent se sentiu em dívida e redigiu, sempre preparando a revisão do Código Civil belga, um tratado maciço, o que fez Catellani ${ }^{9}$ afirmar que "jamais alguma

\footnotetext{
${ }^{5}$ LAURENT, François. Exposé et critique des principes généraux en matière de statuts réels et personnels d'après le droit français. Revue de droit international et de législation comparée, 1869, pp. 244-272.

${ }^{6}$ ESPERSON, Pietro. Movimento giuridico in Italia e nel Belgio sul Diritto internazionale privato. Firenze: Civelli, 1870.

${ }^{7}$ A comissão criada no seio do Institut tinha por objetivo "formular regras gerais que poderiam ser sancionadas por tratados internacionais, em vista de assegurar a decisão uniforme dos conflitos entre diferentes legislações civis e criminais". Dela faziam parte Tobias Asser, Johann Kaspar Bluntschli, Thomas Joseph Lawrence, Pasquale Stanislao Mancini, Gabriel Massé, John Westlake, Charles Brocher, Pietro Esperson, Pasquale Fiore, François Laurent e Carl Ludwig von Bar. Vide, a respeito, MURA, Eloisa. All'ombra di Mancini. La disciplina internazionalistica in Italia ai suoi albori. Pisa: ETS, p. 139.

${ }^{8}$ CATELLANI, Enrico L. Il diritto internazionale privato e i suoi recenti progressi. t. I. Torino: Unione tipograficoeditrice, 1883, pp. 165-166.

${ }^{9}$ Enrico Levi Catellani (1856-1945), novo representante da escola de direito internacional italiana e membro do Institut de droit international, foi professor na Universidade de Pádua de 1885 à 1938, quando foi demitido das suas funções devido à lei racial de 1938, da qual ele teria, como senador, se negado a participar do voto. Vide, a respeito, BARTOLINI, Giulio. Le leggi razziali e la dottrina italiana di diritto internazionale. In: RESTA, Giorgio; ZENOZENCOVICH, Vincenzo (a cura di). Leggi Razziali, Passato/Presente. Roma: Roma TrePress, 2015, pp. 56-76; DE DOI: https://doi.org/10.46699/rduno.v3i4.6031 | Edição Vol. 3, Núm. 4, 2020.
} 
dívida foi cumprida com uma exuberância paralela à sua" ${ }^{10}$. E escrevendo seus oito volumes, cumpriu a promessa que tinha feito ao Institut ${ }^{11}$, dedicando sua obra a Mancini, já considerado como chefe da escola personalista moderna.

\begin{abstract}
Dedico esses Estudos a Mancini, membro do parlamento italiano, Presidente do Institut du droit international. É uma homenagem que faço à Itália, que inaugurou o direito internacional privado, e ao eminente homem sob a inspiração do qual os princípios da nossa ciência têm sido escritos no código italiano. É, ao mesmo tempo, uma dívida que paguei para o Institut, do qual tenho a honra de ser membro. ${ }^{12}$
\end{abstract}

Mancini já tinha entrado em contato em 1867, sendo que os dois homens se encontraram no mesmo ano, na Bélgica ${ }^{13}$, quando o jurista italiano ali se encontrava para negociar um tratado bilateral entre Itália e Bélgica tendo por objeto o exercício dos direitos civis de um Estado no território do outro. Desde então, se comunicavam por correios de tempos em tempos ${ }^{14}$. Os dois homens se admiravam mutuamente e também, no campo político, compartilhavam os mesmos pontos de vista anticlericais. No Avant-Projet de révision du Code civil, Laurent também fazia uma vibrante homenagem a Johann Kaspar Bluntschli, um dos membros fundadores do Institut. Mesmo os dois homens não compartilhando das mesmas opiniões, sentiam um pelo outro grande estima: "Ele morreu há pouco. Permitam-me manifestar a expressão de minha dor ao lamento universal de todos aqueles que conheceram esse homem tão grande e tão bom". ${ }^{15}$

Epígono das teorias de Mancini, o professor de Gante teria igualmente bebido nos escritos dos discípulos do homem público italiano, tais como Giovanni Lomonaco, Pietro Esperson e Pasquale Fiore. Quando preparava o primeiro volume da obra Droit international privé, mencionouo numa carta à Augusto Pierantoni, genro de Mancini, também membro do Institut:

Ocupo-me seriamente de um tratado de direito internacional privado. Será uma obra considerável. [...] Em muitos aspectos é uma glorificação da Itália. [...] além dos trabalhos

\footnotetext{
ROBBIO, Antonella; GIACOMAZZI, Silvia. Storia e memoria di una biblioteca salvata: Il progetto di recupero e valorizzazione del fondo Enrico Catellani all’Università di Padova, Biblioteche oggi, 29 (2011), pp. 47-65.

${ }^{10}$ CATELLANI, Enrico L. Il diritto internazionale privato e i suoi recenti progressi, t. I. Op. cit., p. 166.

${ }^{11}$ LAURENT, François. Avant-Projet de révision du Code civil. t. I. Bruxelles: Bruylant-Christophe, 1883, p. 25.

${ }^{12}$ LAURENT, François. Droit civil international. t. I. Bruxelles: Bruylant-Christophe: 1880-1881, p. VII.

13 LAURENT, François. Carta a Augusto Pierantoni, 29 fevereiro 1879. Archivio dell'Istituto per la storia del Risogimento italiano, $768 \mathrm{n}^{\circ} 120$ (1).

${ }^{14}$ BRUYÈRE, Elisabeth. Principes, esprit et controverses: l'avant-projet de code civil de François Laurent ou l'œuvre séditieuse d'un libre-penseur. Tese de doutorado apresentada na Universiteit Gent (Bélgica), 2019, p. 276.

${ }^{15}$ LAURENT, François. Avant-Projet de révision du Code civil. t. I. Op. cit., p. VII.
} 
de Mancini que você publicou, consultei Esperson, Fiore, Lomonaco. Se existem autores mais recentes sobre o direito civil internacional, queira bem me indicar suas obras. ${ }^{16}$

As obras de Laurent, assim como suas cartas, continham a imensa admiração que nutria por Mancini. As "pré-leis" ("preleggi”), o que são os artigos do título preliminar do Código Civil italiano de 1865, eram para Laurent, uma "gloriosa iniciativa"17. Segundo o professor belga, seu colega italiano, Mancini, "profeta"18 e "nobre órgão da raça italiana"19 no seio de uma Itália "terra privilegiada do direito" 20 , era o mais avançado no domínio do direito internacional privado. Na busca do direito ideal, o direito italiano constituía uma referência na escolha, sendo que Laurent o felicitou por ter trabalhado para dotar de tratados este ramo do direito ${ }^{21}$ : "A Itália abriu a iniciativa dessas negociações. Mancini inaugurou uma nova diplomacia; ele encontra boa acolhida na Bélgica e na Prússia". 22

Em 14 de abril de 1880 Laurent também se apressa a enviar a Mancini o primeiro tomo de seu Droit civil international, há pouco concluído. O jurisconsulto de Gante confiava a seu confrade transalpino que o Código Civil italiano de 1865 era uma grande fonte de inspiração para a redação do seu Avant-Projet:

\footnotetext{
Meu querido colega e amigo,

Envio-lhe o primeiro volume dos meus estudos sobre o direito internacional privado.

Por favor leia o capítulo no qual falo dos Glosadores e os últimos capítulos em que menciono a Itália e você.

Trabalho sempre no meu projeto de revisão do Código Civil. É uma obra imensa. No meu relatório, a cada página examino o Código italiano, frequentemente para o imitar, algumas vezes para o criticar. Quando houver um exemplar impresso, me apressarei para enviá-lo a você $[\ldots]{ }^{23}$
}

As disposições do "Título preliminar" redigidas por Mancini, de fato, eram muito modernas seja pela exaustividade, seja pelo caráter universal. Laurent, enquanto isso, lamentava o fato do jurista italiano estar tão à frente de seu tempo, já que a guerra franco-prussiana tinha reforçado o nacionalismo jurídico e os Estados estavam cada vez menos inclinados à celebrar tratados em

\footnotetext{
${ }^{16}$ LAURENT, François. Carta a Augusto Pierantoni, 29 fevereiro 1879. Archivio dell'Istituto per la storia del Risogimento italiano, $768 \mathrm{n}^{\circ} 120$ (1).

${ }^{17}$ LAURENT, François. Droit civil international. t. I. Op. cit, p. 15.

${ }^{18}$ Idem, p. 73

${ }^{19}$ Idem, p. 72.

${ }^{20}$ Idem, p. 281.

${ }^{21}$ Idem, p. 20.

${ }^{22}$ Idem, p. 40.

${ }^{23}$ Archivio dell'Istituto per la storia del Risorgimento Italiano, 872/8 (3)7.
}

DOI: https://doi.org/10.46699/rduno.v3i4.6031 | Edição Vol. 3, Núm. 4, 2020. 
matéria de direito privado. Fiel a seu caráter otimista, Laurent pensava que isso mudaria ${ }^{24}$. Até decidiu levar ainda mais longe o sistema de Mancini, considerando que esse último teria devido, quando da redação do Código Civil italiano de 1865, fazer um compromisso com as forças conservadoras.

Quando a Revue de droit international publicou uma resenha crítica de E. v. D. R. sobre o Cours élémentaire de Laurent, esse último, sedento para ter a opinião de seu amigo, e aparentemente magoado pelas críticas voltadas à sua obra, se endereça a Mancini: “[A Revista] publicou uma resenha bastante maliciosa sobre a minha obra. É por isso que desejo muito ter a sua opinião. Você me dirá também se esse curso elementar é digno de ser enviado a vossa Accademia dei Lincei" ${ }^{25}$

Sendo já conhecido através de seus Études e de seus Principes pelo apego à noção de nação ${ }^{26}$, o jurisconsulto de Gante se torna, por sua vez - devido a aplicação detalhada que faz do modelo personalista no início dos anos 1880 -, uma referência na reflexão acerca do conflito de leis. Foi considerado por Wharton como "the sturdiest of all recent advocates of the exclusive authority of the law of nationality" 27 . O otimismo que reinava na ciência do direito ${ }^{28}$ e a crença no progresso e no concerto das nações faziam os juristas sonharem com um mundo harmonioso e pacífico ${ }^{29}$. $\mathrm{O}$ personalismo de Mancini se inscrevia no espírito do tempo e Laurent foi daqueles que contribuíram para o fazer brilhar ${ }^{30}$. Quando o deputado belga Hanssens, no âmbito da reforma do ensino superior, pediu a criação de uma cátedra de direito internacional privado, referenciou explicitamente à obra

\footnotetext{
${ }^{24}$ LAURENT, François. Droit civil international. t. I. Op. cit, p. 21.

${ }^{25}$ LAURENT, François. Carta a Pasquale S. Mancini, 1879, Archivio dell'Istituto per la storia del Risorgimento Italiano, 986/26 (2). É Laurent que salientou. A carta foi erroneamente datada de 15 de outubro de 1882.

26 "Os doutíssimos livros do professor Laurent, que lemos atentamente, mostram a evolução social do princípio de nacionalidade através do curso da humanidade". In: PIERANTONI, Augusto. Storia del diritto internazionale nel secolo XIX. Napoli: Marghieri, 1876, p. 117.

${ }^{27}$ ASSER, Tobias M. C.; RIVIER, Alphonse. Éléments de droit international privé ou du conflit des lois. Paris: Rousseau, 1884, pp. 525.

${ }^{28}$ Vide, por exemplo ESPERSON, Pietro. Movimento giuridico in Italia e nel Belgio sul Diritto internazionale privato. Op. cit., p. 3.

${ }^{29}$ É o que Fiore chama de "a coexistência harmoniosa das nações». In: FIORE, Pasquale. Diritto internazionale privato, o principii per risolvere i conflitti tra le legislazioni diverse in matteria di diritto civile e commerciale, Firenze: Le Monnier, 1869, p. 37.

${ }^{30}$ Sobre o movimento pacifista antes de 1870, vide: DE RYCKE, Wouter. The Legal Construction of Peace before 1870. Networks and Arguments. Tese de doutorado em elaboração na Vrije Universiteit de Bruxelas (VUB) (Bélgica).
} 
de Laurent ${ }^{31}$. Enrico Catellani, mal tendo impresso o primeiro volume do seu Diritto internazionale privato $^{32}$, enviou uma cópia a Laurent, na qual redigiu manualmente uma dedicatória ${ }^{33}$ :

Ao Sr. Laurent, na esperança de ter dele algum conselho útil para o futuro, ofereço com a veneração que lhe é devida, como um mestre para todos os jovens que se propõe a consagrar a vida aos estudos históricos e jurídicos e ao amor da liberdade. ${ }^{34}$

Alphonse Rivier, professor de direito internacional na Universidade Livre de Bruxelas, tradutor e comentador da obra de Tobias Asser em matéria de direito internacional privado, constatava que somente os comentários de Laurent no que se refere às dezesseis disposições concernentes ao direito civil internacional no Avant-Projet constituem um "verdadeiro tratado" 35 Sobre o objeto do Droit civil international, ele lamentava, como Brocher, as numerosas digressões "estrangeiras para a ciência do direito" e que a denominação de direito civil internacional não englobava o direito comercial e o direito processual ${ }^{36}$.

\section{Uma teoria universalista}

Tradicionalmente, duas teorias se afrontam no campo do direito internacional privado: o particularismo e o universalismo. De acordo com a ótica particularista, o conflito de leis era um direito estatal, próprio de cada país e, portanto, distinto de cada um deles. O universalismo, ao contrário, via na matéria um direito comum a todos os Estados, ou seja, um direito internacional propriamente dito. Laurent se inseria, na linha de Savigny e de Mancini, nesta segunda categoria ${ }^{37}$. O direito internacional privado era para ele, então, um ramo do direito internacional público - um direito externo ${ }^{38}$-, unívoco em todos os Estados já que conteria regras "universais de sua natureza" ${ }^{39}$. Assim fazendo, se opunha a seu colega Westlake, que considerava o direito

\footnotetext{
${ }^{31}$ Câmara dos representantes, Sessão de 25 de março de 1881, Annales parlementaires 1880/1881, p. 834.

${ }^{32}$ CATELLANI, Enrico L. Il diritto internazionale privato e i suoi recenti progressi. t. I. Torino: Unione tipograficoeditrice, 1883.

${ }^{33}$ Conforme a informação que nos foi dada por A. Sponchiado, nenhuma carta de Laurent se encontra no Fondo Catellani.

${ }^{34}$ Dedicatória de Enrico L. Catellani a François Laurent, escrita em Pádua, em 7 de maio de 1882, contida no exemplar que se encontra na biblioteca da Universidade de Gante.

${ }^{35}$ ASSER, Tobias M. C.; RIVIER, Alphonse. Éléments de droit international privé ou du conflit des lois. Op. cit., p. 19.

${ }^{36}$ Idem, p. 4.

${ }^{37}$ LAURENT, François. Droit civil international. t. I. Op. cit., p. 75.

${ }^{38}$ Idem, p. 10.

${ }^{39}$ LAURENT, François. Droit civil international. Op. cit., t. II, p. 108.
}

DOI: https://doi.org/10.46699/rduno.v3i4.6031 | Edição Vol. 3, Núm. 4, 2020. 
internacional privado como parte do direito nacional ${ }^{40}$ : "Ele rege todas as nações, consideradas como frações da humanidade; e a humanidade sendo uma, o direito deve também ser um só". ${ }^{41}$

Contrariamente ao direito nacional, o direito internacional não teria sua fonte principal na lei, já que essa teria somente uma dimensão territorial e limitada, enquanto o direito internacional privado era, em Laurent, universal. Esse se expressava através de costumes que eram interpretados pelos juízes ${ }^{42}$ : “O direito das gentes é principalmente um direito costumeiro, fundamentado no consentimento tácito dos povos" 43 . Para que haja uma comunidade de direito, o direito aplicado deve ser o mesmo em todas as partes, o que significa que o resultado do litígio seria igual onde quer que estivesse o tribunal que julgaria o mérito do caso. Para isso, o juiz deveria estar preparado para renunciar a lei do foro competente em favor da lei estrangeira ${ }^{44}$.

\section{Uma abordagem fundamentada na teoria dos estatutos}

Encontrar o justo equilíbrio entre territorialidade e personalidade: esse era, para Laurent, o objetivo do direito internacional privado ${ }^{45}$. Tratava-se de determinar quais leis se aplicariam às pessoas, dependendo, portanto, de sua nacionalidade, e quais leis se aplicariam ao território, dependendo do lugar onde a pessoa - ou o bem - se encontrava. Era uma abordagem claramente ligada à teoria dos estatutos, no âmbito da qual Laurent dava, como Mancini, prioridade à personalidade.

A abordagem fundamentada na teoria dos estatutos que marca a atuação de Laurent tinha por objeto a conciliação das diferentes soberanias e de suas atividades legislativas concorrentes. Mais do que resolver os conflitos, tinha por objetivo evitá-los, determinando antecipadamente quais eram as prerrogativas de cada Estado e até onde se estendia o império de suas leis. Em uma ótica universalista, esse sistema cobria o conjunto da comunidade internacional. Normalmente, um indivíduo jamais deveria, portanto, ser tutelado por duas leis nacionais diferentes. Se os tribunais de dois Estados encontravam cada um uma lei aplicável diferente para um mesmo caso em particular, se trataria de uma ocorrência negativa que deveria ser resolvida através de um tratado. $\mathrm{O}$ direito

\footnotetext{
${ }^{40}$ ROLIN-JACQUEMYNS, Gustave. Les principes philosophiques du droit international. Revue de droit international et de législation comparée, 17 (1886), p. 60.

${ }^{41}$ LAURENT, François. Droit civil international. t. I. Op. cit., p. 15.

${ }^{42}$ Idem, p. 74.

${ }^{43}$ Idem, p. 11-12.

${ }^{44}$ LAURENT, François. Droit civil international. t. VIII. Op. cit., p. 29.

${ }^{45}$ LAURENT, François. Droit civil international. t. I. Op. cit., p. 267.
} 
internacional privado era, portanto, necessariamente universal já que constituía um tipo de contrato social à escala das Nações. Essas últimas deveriam todas, portanto, responder pelas mesmas regras, sem o que a repartição das competências não seria équa.

O princípio de nacionalidade desempenharia, finalmente, um duplo papel dialético. De uma parte, justificaria a soberania estatal em torno do conceito de nação no seu aspecto de direito público. De outra, colocaria os limites a esta soberania no que concerne ao direito privado.

\section{Um direito filosófico}

O sistema de direito internacional privado de Laurent se baseava no direito natural conforme os princípios da justiça divina descobertos pela razão. O direito internacional permitia aos povos completar sua missão divina de aperfeiçoamento: "A verdade é uma luz que nós percebemos, somente um raio" 46 . A origem intrínseca do direito internacional privado se encontraria, então, nos princípios do direito natural que regeriam as relações entre os povos e que seriam aplicados a todas as Nações. Esses tomavam corpo nas convenções entre os Estados, sejam essas expressas - os tratados - ou tácitas - os costumes internacionais.

O problema, então, era que infelizmente faltavam tratados, sendo que os juízes eram obrigados a resolver os litígios sem eles. No entanto, Laurent estava reticente em reconhecer, como era seu hábito, qualquer poder ao juiz nessa matéria. Segundo o jurisconsulto de Gante, seria perigoso que o magistrado fosse o intérprete de convenções tácitas. De resto, o caráter extremamente divergente da jurisprudência provava, aos olhos de Laurent, a ineficácia da solução pretoriana.

Estas considerações estavam relacionadas com a crítica de Laurent ao Volksgeist da escola histórica. De fato, ele não acreditava na consciência popular e o ideal da justiça não vinha, segundo ele, "de baixo", mas "do alto". O povo não poderia servir de base para o direito internacional privado já que este era na grande maioria não instruído e não teria ideia das regras que o governam:

\footnotetext{
A consciência geral é também um mito. A imensa maioria dos homens dos quais as nações se compõem não tem a menor ideia de direito e nem mesmo compreende a linguagem jurídica; e há quem queira que a ignorância tenha a consciência de princípios que os juristas consolidados têm dificuldade a compreender $!^{47}$
}

\footnotetext{
46 Idem, p. 193.

${ }^{47}$ Idem, pp. 78-79.
} 
Essa crítica permitia a Laurent desqualificar o direito pretoriano, favorecendo o direito doutrinário.

\section{O direito único, divino e racional}

Devido a essa inspiração filosófico-religiosa, as teorias de Laurent em matéria de direito internacional continham numerosas justificações divinas. Esse foi o caso da abolição do direito de aubana que, aos olhos dele, era o oposto da liberdade que Deus teria deixado aos homens. Não se pode nascer livre e morrer servo, afirmava Laurent ${ }^{48}$. Um outro exemplo era a legalidade no direito de sucessão e a proibição de substituições hereditárias. Conforme Laurent, uma lei humana não poderia contradizer a lei divina ${ }^{49}$. Mas, é isso que fazem os legisladores consagrando o direito de primogenitura:

Deus não faz primogênitos, o homem, portanto, não tem o direito de fazê-los. Isso me parece decisivo, no nosso debate a lei de Deus deve dominar aquela dos homens. A igualdade, princípio de uma verdade eterna, deve prevalecer sobre a desigualdade, que tem um valor somente transitório. ${ }^{50}$

Essas justificações divinas, ligadas à narrativa do progresso, tinham claramente por objetivo, como veremos, proteger o patrimônio da Revolução, notadamente, a laicidade, a igualdade e a liberdade.

Laurent pretendia, portanto, encontrar "a verdade" em matéria de conflito de leis e combater os erros que ali reinavam. Existia, portanto, segundo ele, um e somente um direito internacional privado a ser encontrado, conforme os "verdadeiros" princípios. Esta descoberta era feita utilizando a razão ${ }^{51}$, de onde vinha a utilidade de um trabalho doutrinário. $\mathrm{O}$ doutrinador também estava, ao contrário do magistrado, apto a ler o direito único. A título de exemplo, a realidade das sucessões, a aplicação, para a transmissão de uma sucessão, da lei do Estado no qual se encontravam os bens do de cujus se encontrava em "oposição à natureza das coisas" 52 . Do mesmo

\footnotetext{
${ }^{48}$ LAURENT, François. Droit civil international. t. IV Op. cit., p. 296.

${ }^{49}$ Idem, p. 561.

${ }^{50}$ LAURENT, François. Droit civil international. t. VI. Op. cit., p. 560.

${ }^{51}$ LAURENT, François. Droit civil international. t. III. Op. cit., p. 309.

${ }^{52}$ LAURENT, François. Droit civil international. t. II. Op. cit., p. 233.
}

DOI: https://doi.org/10.46699/rduno.v3i4.6031 | Edição Vol. 3, Núm. 4, 2020. 
modo, a capacidade a contrair casamento era determinada pela lei nacional dos esposos, o que era "racional" e "colocado na essência do casamento"53.

Charles Brocher não deixou de criticar a técnica de Laurent, por ele considerada perigosa. Para o jurisconsulto suíço, Laurent extraía do argumento divino a autoridade para muitas de suas opiniões. Brocher considerava, assim como Rivier, que essas considerações não tinham lugar em uma obra de ciência jurídica ${ }^{54}$.

\section{O direito nacional, o direito progressivo}

Laurent não pensava que o direito fosse chamado a ser mundialmente unificado. Para ele, de fato, a humanidade não se dirigia à unidade perfeita. O professor de Gante pensava, como seu homólogo italiano, que a divisão da humanidade em nações estava na natureza das coisas. Tratavase de uma das teses essenciais de seus Études sur l'histoire de l'humanité. Aos seus olhos, a humanidade apresentava duas características intrínsecas, à saber, a unidade e a diversidade. O direito estava, portanto, no centro de uma dialética constante entre uniformidade e especificidade. Por um lado, enquanto face da vida, tal qual essa última se dirigia para a unidade divina. Por outro, uma parte do direito era contingente. Existia harmonia, portanto, unicamente nas coisas essenciais. As regras de direito internacional privado deveriam fazer parte desses elementos comuns ${ }^{55}$. Para Mancini, igualmente, a ideia de um direito inteiramente comum era um erro porque o esse necessariamente apresentava um aspecto nacional ${ }^{56}$. A irredutibilidade do seu caráter nacional em nada prejudicaria, como afirmava também Laurent, a existência de um direito e de uma justiça transcendental, por definição comum a todos os povos. De maneira geral, certos princípios eram universais, mas restava uma parte do direito que permanecia irredutivelmente adaptada aos diferentes povos devido aos seus próprios costumes.

A lei do progresso, cara a Mancini, assim como ao jurista belga, explicava a melhoria contínua do direito à medida que acontecia a evolução dos costumes e do avanço da ciência. $\mathrm{O}$

\footnotetext{
${ }^{53}$ LAURENT, François. Droit civil international. t. IV. Op. cit., p. 424.

${ }^{54}$ BROCHER, Charles Antoine. Étude sur le traité de droit civil international publié par M. Laurent et sur les principes fondamentaux du droit international privé. Revue de droit international et de législation comparée, 1881, p. 533.

${ }^{55}$ LAURENT, François. Droit civil international. t. II. Op. cit., pp. 366-367.

${ }^{56}$ Mancini, Pasquale Stanislao. De l'utilité de rendre obligatoire, pour tous les États, sous la forme d'un ou de plusieurs traités internationaux, un certain nombre de règles générales du Droit international privé pour assurer la décision uniforme des conflits entre les différentes législations civiles et criminelles. Journal de droit international, 1874, p. 224.
} 
Direito internacional, enquanto isso, para os dois jurisconsultos, ainda não teria conhecido os mesmos avanços que os direitos nacionais modernos. Bem que Laurent tivesse sempre combatido a ideia de estado de natureza entre os homens, mostrava-se hesitante quanto a sua aplicação entre as nações ${ }^{57}$. Essas, não conhecem alguma autoridade superior, o que explicaria o fato de o direito não conseguir se impor nas relações que elas mantém entre si $^{58}$.

\section{PRINCÍPIOS FUNDAMENTAIS DO DIREITO INTERNACIONAL PRIVADO}

\section{A noção central da nação}

\section{Introdução}

Noção central dos Études, a nação - sobre a qual se construíra o Estado moderno -, era o princípio universal da organização do mundo. Já em um artigo de 1860, Laurent a colocava no centro de sua teoria do direito das gentes ${ }^{59}$.

\section{A Nação nas suas origens}

As nações eram em Laurent a expressão da justiça transcendental. Isso significava que o Estado-nação moderno era para ele a atualização de um princípio de justiça divina. Os povos, que sofriam sob o julgo de potências ilegítimas fundamentadas na força e na diplomacia, se organizavam de maneira natural e legítima: finalmente, estavam livres.

O princípio da nacionalidade, por tão longo tempo desconhecido, viu a luz no século dezenove nas revoluções, não há manifestações da justiça divina mais sagradas que essas que ofereçam a vida a uma nação vítima da força. ${ }^{60}$

Esse foi o caso da Grécia, da Bélgica e da Itália ${ }^{61}$. A organização do mundo em nações era chamada a se tornar um princípio universal e eterno, o que favorecia um mundo de paz. Os Estados construídos baseado na conquista e na violência eram, ao contrário, condenados a desaparecer. Esta

\footnotetext{
${ }^{57}$ LAURENT, François. Des doctrines nouvelles sur le droit des gens. La libre Recherche, XVIII (1860), p. 342.

${ }^{58}$ LAURENT, François. Droit civil international. t. I. Op. cit., p. 198.

${ }^{59}$ LAURENT, François. Des doctrines nouvelles sur le droit des gens. Op. cit., p. 340.

${ }^{60}$ LAURENT, François. Droit civil international. t. I. Op. cit., p. 630.

${ }^{61}$ LAURENT, François. Droit civil international. t. III. Op. cit., p. 174; LAURENT, François. Des doctrines nouvelles sur le droit des gens. Op. cit., pp. 336, 355.
}

DOI: https://doi.org/10.46699/rduno.v3i4.6031 | Edição Vol. 3, Núm. 4, 2020. 
noção divina de nação, criação providencial, claramente se distinguia da noção histórica da nação como produto de sua própria história ${ }^{62}$. Em outros termos, a nação em Laurent se identificava mais como uma concepção racional do que romântica.

Segundo André Weiss, existia entre o Estado e o cidadão um vínculo contratual ${ }^{63}$. Edmond Picard igualmente sustentava o caráter consensual do vínculo nacional ${ }^{64}$. Laurent, ao contrário, adotava uma visão mais positivista quando evocava a formação dos Estados. A causa eficiente da nacionalidade e da sujeição a um determinado Estado, mesmo baseado na nacionalidade, era para Laurent um ato de força, fosse uma anexação ou uma revolução ${ }^{65}$. Em continuidade com a sua rejeição ao contrato social, também rejeitava a teoria segundo a qual a formação de um Estado repousava em um suposto acordo de seus cidadãos ou sobre os tratados internacionais que o reconhecem. Segundo o jurista de Gante, a criação de um Estado seria sempre o resultado de atos violentos, que não deixam nenhum espaço para o acordo dos particulares. Essas decisões unilaterais dos Estados vinculavam seus cidadãos a uma nacionalidade, sem que houvesse o consentimento deles. Mesmo quando a anexação era resultado de um plebiscito - quando não era um "simulacro", como aconteceu no caso da anexação da Bélgica à França ${ }^{66}$ - uma minoria era anexada contra sua vontade $^{67}$. Se é levado em consideração o jogo da Providência, a aparente contradição se anula. Os Estados que não eram fundamentados na nacionalidade, eram ficções ${ }^{68}$, e, por isso, destinados a serem subvertidos. Em conclusão, se toda criação do Estado se baseava sobre um ato de força, somente as nações subsistiriam, pela sua legitimidade:

É certo que os impérios criados pela força e fundamentados na destruição das nacionalidades se dissolverão pela força; sobre as suas ruínas se elevarão as nações que Deus chama a uma vida distinta, dando a elas uma diferente missão no desenvolvimento da humanidade. É somente quando essa obra será concluída que a constituição do gênero humano se tornará definitiva. ${ }^{69}$

${ }^{62}$ BROCHER, Charles. Étude sur le traité de droit civil international publié par M. Laurent et sur les principes fondamentaux du droit international privé. Revue de droit international et de législation comparée, 1881, p. 537.

${ }^{63}$ WEISS, André. Manuel de droit international privé. $66^{\mathrm{e}}$ éd. Paris: Sirey, 1909, p. 2.

${ }^{64}$ PICARD, Edmond; D'HOFFSCHMIDT, Napoléon. Pandectes Belges: encyclopédie de législation, de doctrine et de jurisprudence belges. t. 67. Bruxelles: Larcier, 1901, p. 533.

${ }^{65}$ LAURENT, François. Droit civil international. t. III. Op. cit., p. 392.

${ }^{66}$ Idem, p. 389.

${ }^{67}$ LAURENT, François. Principes de droit civil français. t. I. Bruxelles: Bruylant-Christophe, 1869, p. 427.

${ }^{68}$ LAURENT, François. Droit civil international. t. III. Op. cit., p. 174.

${ }^{69}$ Idem, p. 390.

DOI: https://doi.org/10.46699/rduno.v3i4.6031 | Edição Vol. 3, Núm. 4, 2020. 
Como exemplo de conquistas ilegítimas chamadas a sucumbir, Laurent citava a invasão da Polônia pela Rússia ${ }^{70}$, assim como o anexação da Irlanda e da Índia pela Inglaterra ${ }^{71}$.

Nós estamos longe do final deste movimento de nacionalidades; ele apenas começou e está destinado a fazer o giro do mundo. ${ }^{72}$

\section{A Nação no conflito de leis}

O nascimento de um indivíduo no seio de uma nação particular era, como a existência da própria nação, um fato providencial ${ }^{73}$. Divinamente legitimado por essa conclusão, a nacionalidade de um indivíduo deveria desempenhar um papel central na resolução dos conflitos de leis ${ }^{74}$. De fato, o homem deveria responder a leis que eram adaptadas a suas diferenças físicas, intelectuais e morais $^{75}$. Por um lado, no plano físico, o clima teria uma influência tal sobre a nossa pessoa que tornava necessário favorecer a aplicação de nossa lei pessoal ${ }^{76}$. Por outro lado, era preciso privilegiar a lei que era o reflexo de sua personalidade, já que as leis eram, no plano moral, a expressão de suas ideias, de seu ser e de seus sentimentos. Dito de outro modo, cada sistema jurídico era concebido para ser adaptado às especificidades de cada povo, esta é a razão pela qual o direito normalmente tocava os nacionais ${ }^{77}$.

\footnotetext{
As leis são a expressão dos sentimentos, das ideias, frequentemente dos preconceitos da nação que as fez; elas têm o que há de mais íntimo no nosso ser, são uma face da nossa vida, fazem parte do nosso sangue, não poderiam ser separadas da nossa personalidade porque se identificam conosco. ${ }^{78}$
}

Tal qual Mancini, Laurent se opunha ao critério tradicional de vinculação das pessoas, ou seja, o domicílio. Para o professor de Gante era importante que a lei pessoal de um indivíduo tivesse

\footnotetext{
70 “O dia da reparação, da vingança chegará; nenhum crime resta impunido, e a divisão da Polônia é um dos mais horríveis”. In: LAURENT, François. Des doctrines nouvelles sur le droit des gens. Op. cit., p. 361.

${ }^{71}$ LAURENT, François. Droit civil international. t. III. Op. cit., p. 390. “O império inglês é uma criação artificial, que se dissolverá (...)”. In: LAURENT, François. Droit civil international. t. III. Op. cit., p. 261.

${ }^{72}$ LAURENT, François. Des doctrines nouvelles sur le droit des gens. Op. cit., p. 355.

${ }^{73}$ LAURENT, François. Droit civil international. t. IV. Op. cit., p. 389.

${ }^{74}$ LAURENT, François. Droit civil international. t. III. Op. cit., p. 176.

${ }^{75}$ LAURENT, François. Droit civil international. t. II. Op. cit., p. 72.

${ }^{76}$ LAURENT, François. Principes de droit civil. t. I. Op. cit., p. 110.

${ }^{77}$ LAURENT, François. Droit civil international. t. V. Op. cit., p. 82.

${ }^{78}$ LAURENT, François. Avant-Projet de révision du Code civil. t. I. Op. cit., pp. 70-71
} 
uma certa coerência no tempo. O domicílio, feito de acaso e de capricho ${ }^{79}$, era para ele somente um "estabelecimento temporário" 80 , que poderia ser alterado por uma simples visita à prefeitura, não tendo alguma pertinência na determinação do estatuto pessoal. Por outro, seria incoerente que a capacidade da pessoa fosse alterada à vontade pela modificação do domicílio. A nacionalidade igualmente teria a preferência de Mancini em relação ao domicílio - proposto por Savigny -, devido ao caráter estável que fornecia ao estatuto pessoal ${ }^{81}$. Critério contido embrionariamente no código napoleônico, a nacionalidade não era, segundo Laurent, acidental, mas traduzia o vínculo moral e afetivo que unia o cidadão e sua nação ${ }^{82}$. Tendo dito isso, a aplicação do critério do domicílio se justificava no seio de Estados em que o direito não era unificado (vide 2.1.5) ${ }^{83}$.

\section{O Estado nos seus desenvolvimentos posteriores}

Laurent não forneceu numerosos elementos para a definição da nação. E não sem razão, porque identificava globalmente nação e Estado ${ }^{84}$. O Estado era, no final, somente uma nação politicamente organizada e reconhecida pelas potências estrangeiras. O princípio de nacionalidade encontrava por modelo os Estados-nação típicos do XIX século, tais como a Itália e a Alemanha unificados. A nacionalidade era, portanto, o pertencer a um Estado. O princípio de nacionalidade justificava bastante a formação do Estado, através do princípio da autodeterminação dos povos, sendo que Estado e nação tinham, além disso, uma outra relação dialética: se a nação criava o Estado, o inverso igualmente se verificava. Deste modo, a "raça negra" e a "raça branca" formavam nos Estados Unidos uma só e a mesma nacionalidade, e os diferentes povos que se instalaram no Novo Mundo se misturaram com a finalidade de formar uma nova nação.

Esta confusão de direitos diferentes é impossível nas nossas ideias modernas sobre o Estado; todas estas populações de origem diferente formam somente um Estado, todas têm uma pátria comum, e nesse sentido uma mesma nacionalidade; deixo de lado os chineses e os selvagens. ${ }^{85}$

\footnotetext{
${ }^{79}$ LAURENT, François. Droit civil international. t. II. Op. cit., p. 188.

${ }^{80}$ LAURENT, François. Droit civil international. t. III. Op. cit., p. 451.

${ }^{81}$ HALPÉRIN, Jean-Louis. Entre nationalisme juridique et communauté de droit. Paris: PUF, p. 74.

${ }^{82}$ LAURENT, François. Droit civil international. t. III. Op. cit., p. 443.

${ }^{83}$ Idem, p. 441.

${ }^{84}$ Idem, p. 177.

${ }^{85}$ Idem, p. 441.
}

DOI: https://doi.org/10.46699/rduno.v3i4.6031 | Edição Vol. 3, Núm. 4, 2020. 
Não está claro, no entanto, porque Laurent diz “deixo de lado os chineses e os selvagens" $" 86$... Se a nação justificava o Estado no seu final, havia mais preocupação sobre isso uma vez que o Estado constituía uma realidade tangível. O civilista, de fato, quando aplicava o princípio da nacionalidade, buscava unicamente saber de qual Estado o indivíduo era proveniente, ou seja, de qual país era cidadão. A esse respeito, André Weiss era bem mais explícito, distinguindo claramente nação e Estado, mas declarando que não era papel do jurista avaliar se o Estado era fundamentado no princípio de nacionalidade ${ }^{87}$. Jessurun d'Oliveira contestou a utilidade científica desse tema em Laurent $^{88}$. E por uma boa razão, esse princípio não se referia ao privatista. Quando a cidadania do indivíduo não era objeto de nenhuma controvérsia, não pertencia ao jurista, se tornando uma questão de conflito de leis, de questionar a legitimidade nacional do Estado designado, ainda mais quando a natureza transitória das divisões políticas europeias não poderia, argumentou Laurent, paralisar a resolução dos conflitos de leis atuais ${ }^{89}$.

\section{Face ao pluralismo jurídico}

Onde a religião não é um obstáculo absoluto, as raças acabam por se confundir sob uma única lei. ${ }^{90}$

Vimos que, para Mancini, a unidade jurídica era, em um Estado, uma necessidade absoluta. O mesmo acontecia em Laurent, porque a unificação do direito era um fenômeno inevitável, intrinsicamente ligado, como a codificação, à organização moderna do Estado $^{91}$. O princípio de nacionalidade não considerava a priori, portanto, os pluralismos jurídicos. Se desejavam ardentemente a unidade legislativa, os autores não ignoravam, por outro lado, que outros Estados funcionavam de um modo diferente. Também Laurent notava o pluralismo jurídico reinante nos grandes países como os Estados Unidos. Por isso preconizava, em caso do império da lei pessoal, a

\footnotetext{
${ }^{86}$ Em outra oportunidade, Laurent igualmente declarava: "Os Chineses que vem a se estabelecer nos Estados Unidos permanecem Chineses, de religião, de caráter, de meios; aquilo que é verdade sobre as raças é também verdade sobre as nacionalidades". In: LAURENT, François. Droit civil international. t. II. Op. cit., p. 205.

${ }^{87}$ WEISS, André. Manuel de droit international privé. Op. cit., p. 2.

${ }^{88}$ JESSURUN D'OLIVEIRA, Hans Ulrich. Principe de nationalité et droit de nationalité, Notes de lecture au sujet du Droit civil international de François Laurent. In: ERAUW, Johan; BOUCKAERT, Boudewijn; BOCKEN, Hubert; GAUS, Helmut; STORME, Marcel (dir.). Liber Memorialis François Laurent. Bruxelles: Story-Scientia, 1989, p. 831. ${ }^{89}$ LAURENT, François. Droit civil international. t. I. Op. cit., p. 626.

${ }^{90}$ LAURENT, François. Droit civil international. t. V. Op. cit., p. 447.

${ }^{91}$ LAURENT, François. Droit civil international. t. III. Op. cit., p. 449.
} 
aplicação ao cidadão americano do direito de seu domicílio. Na ausência do código civil alemão, o direito pessoal de um alemão seria igualmente aquele de seu domicílio. Quanto ao cidadão britânico, é o seu domicílio que deveria determinar a eleição do direito escocês ou inglês ${ }^{92}$. Laurent notava, ainda, que também era pluralismo jurídico o fato de Estados permitirem a minorias religiosas utilizarem seu direito tradicional, como a possibilidade dos judeus de deixarem testamento segundo a antiga lei hebraica no Império otomano ou na Tunísia. O jurista de Gante admitia, portanto, que a lei pessoal do turco judeu seria, em matéria de testamentos, a lei hebraica. A aplicação da lei hebraica para um judeu belga, ao contrário, colidiria com os princípios de laicidade e de igualdade dos cidadãos perante a lei que se encontravam no fundamento do Estado belga ${ }^{93}$.

\section{A Nação inclusiva}

O nacionalismo de Laurent, como aquele de Mancini, não era exclusivo, por várias razões. A teoria das raças, influente mas não determinante, deveria deixar lugar suficiente para o livre arbítrio. Por primeiro, mesmo se Laurent frequentemente utilizava o termo raça, a nacionalidade e a raça eram duas coisas diferentes. Nos seus Études, tentou longamente demolir o termo raça, cunhado por Ernest Renan, que minou o princípio fundamental da unidade do gênero humano ${ }^{94}$. O princípio de nacionalidade não justificava, para Laurent, o isolamento dos diferentes povos, sendo, ao contrário, necessário favorecer a mistura das populações. As raças se misturariam, como nos Estados Unidos, a fim de fomentar novas nações e por força dessas misturas as raças desapareceriam para deixar espaço somente às nações, cujos membros não serão mais fisicamente diferentes.

A liberdade do indivíduo se opõe ao vínculo ilimitado à sua pátria de origem. $\mathrm{O}$ cidadão de um Estado deveria, então, ter a possibilidade de renunciar a sua lei pessoal. De início, suporia a liberdade de mudar de nação, se estabelecendo em um país sem vontade de retornar. O indivíduo poderia, emigrando, aderir ao projeto de um outro Estado e adquirir a nacionalidade desse último. Laurent admitia, como Edmond Picard ${ }^{95}$, uma verdadeira liberdade de emigração ${ }^{96}$, direito natural que as leis positivas não poderiam contradizer ${ }^{97}$, partindo da liberdade individual consagrada pela

\footnotetext{
${ }^{92}$ Idem, p. 440.

${ }^{93}$ LAURENT, François. Droit civil international. t. VI. Op. cit., p. 685.

${ }^{94}$ LAURENT, François. Études sur l'histoire de l'humanité. La philosophie de l'Histoire. t. XVIII. Bruxelles: Lacroix, 1870, p. 133.

${ }^{95}$ PICARD, Edmond; D'HOFFSCHMIDT, Napoléon. e.a., Pandectes Belges, t. 67, op. cit., p. 535.

${ }^{96}$ LAURENT, François. Droit civil international. t. V. Op. cit., pp. 339-340.

${ }^{97}$ LAURENT, François. Droit civil international. t. III. Op. cit., p. 372.
} 
Declaração dos Direitos do Homem ${ }^{98}$. O estrangeiro se estabelecendo de boa fé em um Estado e adquirindo a nacionalidade desse não responderia mais à sua lei nacional de origem. A esse respeito, Laurent desejava que se concedesse mais facilmente a grande naturalização. A seguir, o indivíduo que nascesse de pais estrangeiros não deveria conservar a nacionalidade de seus genitores, mas adquirir aquela da pátria de adoção, pátria de seus sentimentos. Essa era uma das consequências do aspecto moral da nacionalidade.

Jessurun d'Oliveira não compreendeu a ligação existente entre o personalismo promovido por Laurent no direito internacional privado e o territorialismo que o mesmo defendia em matéria de direito da nacionalidade ${ }^{99}$. No entanto, os dois princípios eram complementares. O princípio de nacionalidade, devido ao fato de poder ser conciliável com a liberdade individual, era indissociável de um direito à mobilidade física ou de um direito à emigração e de um direito à mobilidade jurídica ou de um direito à nacionalidade. Ainda, conforme Laurent, o vínculo de subordinação a uma pátria não poderia ser perpétuo, caso contrário destruiria a liberdade individual. Ademais, a aplicação da lei pessoal, visando o desenvolvimento individual, deveria ser feito para o benefício da pessoa e não pesar indefinidamente como um jugo sobre ela e sua descendência. A nacionalidade, consequentemente, não teria nada de absoluto e comportava uma boa parte de voluntarismo, que o Avant-Projet de révision du Code civil tornou possível devido aos aspectos territorialistas da legislação sobre o indigenato.

\section{Os limites do estatalismo de Laurent}

O Estado possuía um lugar primordial no pensamento de Laurent, sendo considerado uma criação no interesse do indivíduo. As suas teorias em matéria de conflitos de leis também minaram o estatalismo que defendia. É o caso, justamente, do direito civil internacional que, devido ao seu caráter obrigatório, acabava por limitar as prerrogativas estatais.

\section{As três armadilhas da naturalidade do personalismo nacionalista}

\section{Primeira armadilha. A batalha da ordo nova contra a ordo antiga}

\footnotetext{
${ }^{98}$ LAURENT, François. Principes de droit civil. t. I. Op. cit., p. 425.

99 JESSURUN D’OLIVEIRA, Hans Ulrich. Principe de nationalité et droit de nationalité. Op. cit., pp. 826 et s. 
Na sua defesa do personalismo, Laurent percebeu que tinha contra si a tendência claramente territorialista do antigo direito, algo que poderia colocar em perigo a defesa do caráter natural de seu sistema. O elogio ao personalismo de Mancini estava, portanto, alinhado com um repúdio - ao menos parcial - da tradição que Laurent qualificava de "tirânica" ${ }^{100}$, com a finalidade de adotar, ao contrário, um direito natural progressivo, voltado para o futuro. Uma grande parte de sua retórica se cristalizava em torno desta luta entre passado e futuro. Colocando-se como mensageiro do progresso, declarava com um pouco de provocação que "cabe ao legislador belga ver se quer permanecer alinhado com a tradição medieval ou se quer colocar o novo Código em harmonia com o progresso da doutrina e da legislação". ${ }^{101}$

A obra napoleônica de 1804, para Laurent, negou numerosos princípios consagrados pela Revolução, que tinham conduzido a um maior reconhecimento dos direitos civis do estrangeiro ${ }^{102}$. O objetivo do jurista de Gante era, portanto, retornar aos valores de 1789. Para provar o quanto sua teoria era bem fundamentada, combinava a lógica à história, deduzindo da história das relações internacionais os princípios que deveriam presidir o direito das gentes. Para tanto, observava os valores que ao longo da história se tornavam claros e disso concluia, através da teoria do progresso, que eram os únicos que poderiam governar as relações entre os povos, entre essas os conflitos de leis. Já que Deus se manifestou através da história, por meio das ações dos homens, entendidos a longo prazo, o advento do direito se fazia pouco a pouco. Assim, como o mundo antigo respondia à regra da força, hoje é o reino de Deus a governar afirmando progressivamente sua vitória sobre o que foi feito por meio das Revoluções, que foram testemunhos da justiça divina ${ }^{103}$. Laurent tinha esperança que esses princípios de justiça eterna seriam reunidos por todas as nações.

Para Charles Brocher, esta manifestação de Deus através da história afirmada por Laurent não era razoável e destruía a liberdade e a responsabilidade do ser humano ${ }^{104}$. Para o jurista suíço, o progresso se encontrava no movimento de laicização da lei do progresso, sendo um ato racional do homem e não uma consequência da Providência Divina.

O territorialismo, o particularismo e o critério do domicílio eram, para Laurent, características do mundo antigo, o que significava o mundo pré-revolucionário. A feudalidade tinha desaparecido

\footnotetext{
${ }^{100}$ LAURENT, François. Droit civil international. t. VI. Op. cit., p. 46.

${ }^{101}$ LAURENT, François. Avant-Projet de révision du Code civil. t. I. Op. cit., p. 29.

${ }^{102}$ LOCHAK, Danièle. L'étranger dans le Code civil. In: BLOCH, Pascale; DUVERT, Cyrylle; SAUPHANORBROUILLAUD, Natacha. Différenciation et indifférenciation des personnes dans le code civil. Paris: Economica, 2006, p. 110.

${ }^{103}$ LAURENT, François. Droit civil international. t. I. Op. cit., p. 630.

${ }^{104}$ BROCHER, Charles. Étude sur le traité de droit civil international publié par M. Laurent. Op. cit., p. 536.
}

DOI: https://doi.org/10.46699/rduno.v3i4.6031 | Edição Vol. 3, Núm. 4, 2020. 
deixando lugar a um novo regime político, mas também a um novo mundo econômico, em que os povos não eram mais inimigos. As nações, com o objetivo de se reaproximarem, deveriam reconhecer mutuamente os direitos dos emigrados. A Modernidade impôs, portanto, a escolha do personalismo e do princípio de nacionalidade: "Declarar o estatuto real para toda a sucessão é recuar até a idade média". 105

O pessimismo antropológico do Consulado passava a ser sucedido por um verdadeiro otimismo internacionalista e pacifista, em que Laurent estava empenhado procurando convencer os ordenamentos jurídicos nacionais a efetuar um leap of faith, reconhecendo explicitamente os direitos dos estrangeiros e permitindo a esses últimos serem regidos pelas leis nacionais ${ }^{106}$.

\section{Segunda armadilha. Um direito divino, mas não cristão}

Promovendo um direito filosófico, Laurent teve de ter cuidado para não promover a moral cristã, já que na sua ótica, o cristianismo destruíra a nacionalidade ao defender uma ordem jurídica mundial ${ }^{107}$. A universalidade integral do direito viria, então, de um preconceito cristão ${ }^{108}$. O direito cristão sufocaria as soberanias e os Estados ${ }^{109}$, prejudicando, assim, o fundamento do sistema. Por esse motivo o nacionalismo teria em Laurent uma certa dimensão anticlerical, algo característico do pensamento de numerosos homens do Institut ${ }^{110}$. À título de exemplo, a noção de "bonnes moeurs", que poderia constituir um obstáculo à lei nacional do estrangeiro, tocava na moral, mas deveria ser interpretada sem referência à moral católica ${ }^{111}$. Era necessário, ao contrário, levar em consideração as "crenças fundamentais que se encontram em todas as religiões"112; "Roma católica comprometeu, melhor dizendo, destruiu a soberania do Estado e a independência das nações". ${ }^{113}$

Além disso, o direito cristão constituía, aos olhos de Mancini e de Laurent, um obstáculo à igualdade entre os $\operatorname{povos}^{114}$ : não sendo tolerante, não poderia ser voltado a todos. Se, por um lado,

\footnotetext{
${ }^{105}$ LAURENT, François. Avant-Projet de révision du Code civil. t. I Op. cit., p. 48.

${ }^{106}$ ESPERSON, Pietro Movimento giuridico in Italia e nel Belgio sul Diritto internazionale privato. Op. cit., p. 28.

${ }^{107}$ LAURENT, François. Des doctrines nouvelles sur le droit des gens. Op. cit., p. 542.

${ }^{108}$ LAURENT, François. Droit civil international. t. I. Op. cit., pp. 183 ss.

${ }^{109}$ Idem, p. 203.

${ }^{110}$ KOSKENNIEMI, Martti. The gentle civilizer of nations. The rise and fall of International Law 1870-1960. Cambridge: Cambridge University Press, 2001, p. 65.

${ }^{111}$ LAURENT, François. Droit civil international. t. II. Op. cit., p. 377.

112 Idem, p. 378.

${ }^{113}$ LAURENT, François. Des doctrines nouvelles sur le droit des gens. Op. cit., p. 350.

${ }^{114}$ Idem, p. 347.
}

DOI: https://doi.org/10.46699/rduno.v3i4.6031 | Edição Vol. 3, Núm. 4, 2020. 
o cristianismo tinha constituído uma melhora na história das relações entre os povos, instaurando entre eles uma unidade religiosa, por outro, favorecia a rejeição do não-cristão, fenômeno que teria permitido a dominação de povos colonizados. A esse respeito, Laurent apontava o dedo, por diversas vezes, contra as legislações dos países cristãos que consagravam a incapacidade dos judeus:

\begin{abstract}
O Grande Conselho do cantão de Basileia-Campagne tinha agido conforme o cristianismo tradicional: os judeus estão condenados à escravidão perpétua, estão fora da lei; não há direito das gentes para eles. Esse é o direito das gentes cristão em meados do XIX século. Se existe um direito para os não-fiéis, é graças à filosofia, que liberou as consciências dos preconceitos da intolerância cristã. ${ }^{115}$
\end{abstract}

Conforme Laurent e Mancini, era na qualidade de Ser Humano que se apoiava o direito universal. Ambos, levados pelos mesmos princípios do liberalismo filosófico, acreditavam na existência de uma moral universal a qual Savigny, para quem a cristandade era a base dessa comunidade de direito, não poderia concordar.

\title{
Terceira armadilha: $O$ obstáculo legalista
}

O legalismo reinante no XIX século e, em particular, na própria obra de Laurent, era um obstáculo na fundação de seu sistema, baseado no direito natural. Cheio de contradições, o jurista de Gante algumas vezes expressava suas dúvidas quanto à existência de um direito natural aplicável à comunidade internacional. Enquanto fiel à codificação, estava desconfortável com a ausência de uma norma escrita sobre a matéria. Em todo caso, para ele era certo que o juiz não tinha o poder de invocar o direito das gentes com a finalidade de descartar o Código ${ }^{116}$. Nessa perspectiva, protestou contra um acórdão da Corte de Cassação de 1849, que baseava o estatuto pessoal do estrangeiro no direito das gentes. De fato, a Corte de Cassação, em 8 de fevereiro de 1849, negando o caráter bilateral do artigo terceiro, parágrafo primeiro, fundamentava a aplicação ao estrangeiro da sua lei pessoal nos princípios de "direito das gentes fundados sobre o uso universal dos povos" ${ }^{117}$. Assim fazendo, a alta Corte reviu a sua jurisprudência de 1847, em que tinha invocado a bilateralidade do $\operatorname{artigo~terceiro~}^{118}$. Para Laurent, tal qual aconteceu em 1847, a Corte deveria ter invocado por

\footnotetext{
${ }^{115}$ LAURENT, François. Droit civil international. t. II. Op. cit., pp. 59-60.

${ }^{116}$ LAURENT, François. Droit civil international. t. I. Op. cit., p. 38.

${ }^{117}$ Acórdão da Corte de Cassação de 8 de fevereiro de 1849, Pasicrisie, 1849, I, p. 239.

${ }^{118}$ Corte de Cassação, 22 de julho de 1847, Pasicrisie, 1847, I, p. 392.
} 
analogia o Código, ou seja, o artigo terceiro, alínea três, e, também, a tradição, ou seja, a teoria clássica dos estatutos.

Ao decidir fazer a aplicação do direito das gentes de maneira autônoma, a Corte, na opinião do jurista de Gante, acabou por colocar o ius gentium na frente da lei, o que para ele era inadmissível. Não teria havido, para ele, "uso universal dos povos" devido ao fato da doutrina naquele momento estar longe de ser unívoca e os países de Common Law não reconhecerem tais princípios ${ }^{119}$. A irritação com a decisão judicial se deu, justamente, porque ele sempre afirmou a existência de princípios de ius gentium invocados pela Corte, sendo que a jurisprudência, ao contrário, se deu a liberdade de ler os princípios em si, sem se fundamentar na doutrina. Não era função do magistrado decretar os contornos do ius gentium. Ademais, um problema maior surgiria se o direito das gentes fosse aplicado diretamente sem passar pelo Código: o critério de domicílio, e não aquele de nacionalidade, era de um ponto de vista internacional, o mais difuso. O domicílio era, por outro lado, algumas vezes invocado pela jurisprudência belga ${ }^{120}$.

Nos anos 1880, a Corte cessa de invocar o argumento do ius gentium para se referir ao Código - sem ainda mencionar a analogia -, algo que se faz, segundo Marc Fallon, por influência da doutrina de Laurent ${ }^{121}$. De fato, em um dos acórdãos ligados ao caso de Bauffremont ${ }^{122}$, em 1882, a Corte aplica o artigo terceiro, que era, segundo a alta jurisdição, a aplicação do "princípio" de personalidade:

\footnotetext{
Considerando que é de princípio que o estado e a capacidade das pessoas são regulados pelas leis da nação a qual pertencem,

Considerando que, deste princípio aplicado e implicitamente consagrado pelo artigo 3 , parágrafo primeiro, do código civil, pode-se induzir que as disposições de um julgamento, emanado em um país estrangeiro sobre o estatuto pessoal de um cidadão daquele país, tem força de coisa julgada na Bélgica $[\ldots]^{123}$
}

\footnotetext{
${ }^{119}$ LAURENT, François. Droit civil international. t. II. Op. cit., p. 81.

${ }^{120}$ FALLON, Marc. L'application de l'article 3, alinéa 3, du Code civil par la jurisprudence belge du XIX ${ }^{\mathrm{e}}$ siècle. In: ERAUW, Johan; BOUCKAERT, Boudewijn; BOCKEN, Hubert; GAUS, Helmut; STORME, Marcel (dir.). Liber Memorialis François Laurent. Bruxelles: Scientia, 1989, p. 775.

${ }^{121}$ Idem, p. 771.

${ }^{122} \mathrm{O}$ caso Bauffremont era um célebre caso de direito internacional privado do último terço do século XIX. A esposa do Príncipe de Bauffremont, do qual estava com separação de corpos, adota a nacionalidade alemã a fim de poder se divorciar e casar com o Príncipe Bibesco. É colocada a questão relativa a saber se esta mudança de nacionalide era regular. Vide, TEICHMANN, Albert. Étude sur l'affaire de Bauffremont, envisagée au point de vue des législations française et allemande. Bâle: Meyri's Buchhandlung, 1876, p. 9.

${ }^{123}$ Corte de Cassação, 19 de janeiro de 1882, Pas. 1882 p. 40. É o que nós sublinhamos.
} 
Não havia menção a um raciocínio analógico, mas a referência ao direito das gentes e a reciprocidade já estava ausente. A Corte procurou a resolução do caso na noção sibilina de "princípio", sem especificar se tratava-se de um princípio de direito das gentes, de um princípio tradicional ou de um princípio de direito civil.

\section{O gozo dos direitos civis por parte dos estrangeiros}

$\mathrm{O}$ primeiro princípio fundamental em matéria de direito internacional privado era $\mathrm{o}$ reconhecimento do estrangeiro como pessoa de direito. No projeto de Laurent, o indivíduo não tendo a nacionalidade belga deveria ser, nos termos do direito civil, igual ao cidadão do Reino da Bélgica. Todos os dois deveriam poder ser titulares dos mesmos direitos e obrigações, condição que Laurent anunciava já de início no Préface de seu Avant-Projet, "Lettre à M. le Ministre de la Justice": "O avant-projet proclama a igualdade dos estrangeiros e dos nacionais no que concerne ao gozo dos direitos civis". ${ }^{24}$

Seu ponto de apoio mais forte para esta regra era o Código Civil italiano de $1865^{125}$. O destinatário do direito civil não era, portanto, o cidadão, mas a Pessoa. Fundamentalmente, Laurent justificava isso através do fato que a ideia de Justiça não dependia do Estado, mas sim do Divino, e que, portanto, deveria ser aplicada a todos os humanos e não somente aos nacionais ${ }^{126}$. As mesmas ideias eram encontradas em Pietro Esperson. Conforme o jurista italiano, os homens faziam parte de uma mesma família ${ }^{127}$. Por outro lado, arguia Esperson, a liberdade de emigrar seria ilusória se, emigrando, o homem perdia o uso dos direitos civis ${ }^{128}$. O artigo 50 do Avant-Projet de révision du Code civil reportava, portanto, que: "Toda pessoa goza de direitos civis. Os belgas podem ser privados deste gozo nos casos previstos pelo Código penal". ${ }^{129}$

Este artigo, referente a 143.000 estrangeiros que viviam na Bélgica ${ }^{130}$, vinha a substituir o artigo 8 do Código napoleônico, que estatuía que "Todo francês gozará dos direitos civis" e constituía, para Laurent, somente a sequência lógica da abolição do direito de aubana, acontecida

\footnotetext{
${ }^{124}$ LAURENT, François. Avant-Projet de révision du Code civil. t. I. Op. cit., p. III.

${ }^{125}$ Código civil italiano de 1865: "Artigo 3. O estrangeiro é admitido a gozar dos direitos civis atribuídos aos cidadãos".

${ }^{126}$ LAURENT, François. Droit civil international. t. IV. Op. cit., p. 27.

${ }^{127}$ ESPERSON, Pietro. Il principio di nazionalità, applicato alle relazioni civili internazionali. Pavia: Fusi, 1868, p. 2. ${ }^{128}$ Idem, p. 9.

${ }^{129}$ LAURENT, François. Avant-Projet de révision du Code civil. t. I. Op. cit., p. 239.

${ }^{130}$ COUPAIN, Nicolas. L'expulsion des étrangers en Belgique (1830-1914). Revue belge d'histoire contemporaine, XXXIII (2003), p. 7.
}

DOI: https://doi.org/10.46699/rduno.v3i4.6031 | Edição Vol. 3, Núm. 4, 2020. 
em 1865. Ademais, os estrangeiros deveriam igualmente dispor de igual acesso aos tribunais, mesmo para os litígios entre eles, o que a jurisprudência francesa admitia somente por exceção ${ }^{131}$. Na Bélgica, a jurisprudência originalmente reconhecia esta competência, mas houve uma reversão com a extensa concepção da jurisdição. O conflito foi finalmente resolvido pelo Livre préliminaire do novo Código de processo de 1876, que permitia essa competência ${ }^{132}$.

Assim fazendo, Laurent abolia a distinção entre direitos civis e direitos naturais que se encontrava na doutrina majoritária do Código Civil $^{133}$. O conjunto de direitos privados deveriam ser, então, considerados como naturais ${ }^{134}$, por serem todos necessários ao desenvolvimento do Homem. Ninguém poderia, segundo o professor de Gante, ser deles privado tendo por base sua nacionalidade. A título de exemplo, a adoção deveria se tornar um direito natural, estando então, ao alcance dos estrangeiros, como dos nacionais, o que não acontecia anteriormente ${ }^{135}$. Laurent denunciava igualmente o fato de que, na Bélgica, somente os nacionais teriam acesso aos advogados pro deo, algo que qualificava como "bárbaro"136.

Ademais, nos artigos 11 e seguintes do Avant-Projet de révision du Code civil constava a bilateralidade do direito internacional privado, algo que faltava, como foi visto, no Código napoleônico. O princípio de bilateralidade tinha, para Laurent, um fundamento divino ${ }^{137}$. Os indivíduos, nacionais ou não, deveriam ser tratados do mesmo modo, por serem todos filhos de Deus. Nesse contexto, vinha salientado o papel que o catolicismo desempenhava nesta unidade já que a Igreja estava na origem de uma comunidade de direito, graças à igualdade professada pelo cristianismo $^{138}$. Porém, no cristianismo esta igualdade celeste não era civil, já que os homens restavam iniguais na terra.

O professor de Gante salientava que "a subdivisão do gênero humano em nações não tinha alguma influência sobre os direitos privados" e reclamava do "patriotismo exclusivo e estreito dos

\footnotetext{
${ }^{131}$ LAURENT, François. Droit civil international. t. IV. Op. cit., p. 69.

${ }^{132}$ VANKEERSBILCK, Maarten. Justitie in de steigers: gerechtelijke hervormingen in belgië, De moeizame weg naar het gerechtelijk wetboek. Tese de doutorado apresentada na Universiteit Gent (Bélgica), 2019, pp. 104 et s.

${ }^{133} \mathrm{Na}$ interpretação majoritária do Código civil, nessa compreendida também aquela de Laurent de lege lata, os direitos naturais seriam concedidos de ofício aos estrangeiros, notadamente, o direito de propriedade, o direito de contratar etc. Os direitos civis, considerados como nacionais ou contingentes, eram aqueles que se colocavam como um ato de soberania, não existindo necessariamente em todas as nações "civilizadas" e para os quais se aplicava a dupla condição de reciprocidade prevista pelo Código napoleônico.

${ }^{134}$ LAURENT, François. Avant-Projet de révision du Code civil. t. I. Op. cit., p. 24.

${ }^{135}$ LAURENT, François. Droit civil international. t. II. Op. cit., p. 64.

${ }^{136}$ LAURENT, François. Droit civil international. t. IV. Op. cit., pp. 28-29.

${ }^{137}$ LAURENT, François. Droit civil international. t. I. Op. cit., p. 22.

${ }^{138}$ Idem, p. 49.
}

DOI: https://doi.org/10.46699/rduno.v3i4.6031 | Edição Vol. 3, Núm. 4, 2020. 
antigos" ${ }^{139}$. Esses aspectos da sua teoria deviam muito a Savigny, precursor do direito internacional privado moderno. A igualdade era já defendida pelo jurista de Berlim, que pedia a abolição do princípio de reciprocidade e o gozo dos direitos civis por estrangeiros sem que fossem interpostos condicionamentos ${ }^{140}$. A doutrina de Laurent e da escola italiana era, portanto, internacionalista, ao mesmo tempo que nacionalista.

\section{A personalidade das leis}

O segundo grande princípio do direito internacional em Laurent residia na mudança de paradigma em relação ao Código napoleônico: toda disposição era um princípio pessoal, as disposições de aplicação real somente constituíam uma exceção. Como foi visto, o Código Civil admitia o personalismo somente para o estado e a capacidade da pessoa. Ademais, usava somente meias-palavras, obrigando os intérpretes a deduzir a sua bilateralidade:

\footnotetext{
Artigo 11. As leis concernentes ao estado e a capacidade das pessoas regem os belgas em todos os lugares onde eles se encontram.

As leis estrangeiras concernentes ao estado e a capacidade regem os estrangeiros que se encontram na Bélgica, até o momento em que eles tenham adquirido a nacionalidade belga. ${ }^{141}$
}

Poderiam ser possíveis apoios na defesa do personalismo a doutrina italiana, portanto, evidentemente Mancini, e a doutrina alemã, notadamente aquela de Savigny. O personalismo desse último, contudo, poderia constituir somente um fundamento incompleto, já que, como anteriormente visto, tinha por ponto de ruptura o domicílio da pessoa, justamente quando Laurent pretendia promover a nacionalidade ${ }^{142}$. O modelo seguido, então, era aquele oferecido pelo Código Civil italiano, indo, contudo, além dele: mesmo as regras referentes aos imóveis deveriam se tornar pessoais. Em virtude do Avant-Projet de révision du Code civil, o estatuto pessoal de um apátrida era aquele do seu domicílio, ou, na falta desse, de sua residência (artigo 18). A comissão de revisão não seguiu esse princípio e optou pela aplicação da lex fori, ou seja, a lei belga ${ }^{143}$.

\footnotetext{
${ }^{139}$ LAURENT, François. Avant-Projet de révision du Code civil. t. I. Op. cit., p. 240.

${ }^{140}$ ANCEL, Bertrand. Élements d'histoire du droit international privé. Paris: Panthéon-Assas, 2017, p. 481.

${ }^{141}$ LAURENT, François. Avant-Projet de révision du Code civil. t. I. Op. cit., p. 24.

${ }^{142}$ ANCEL, Bertrand. Élements d'histoire du droit international privé. Op. cit., p. 476.

${ }^{143}$ AA. Révision du Code civil belge. Revue de droit international et de législation comparée, 1886, p. 492.
} 
Anteriormente foi mencionado que a legitimidade do critério de nacionalidade repousava no fato dessa última constituir, para Laurent, um fato ligado à Providência Divina. Ademais, o personalismo, segundo o autor, era somente a consequência do princípio da igualdade entre o estrangeiro e o nacional do Reino da Bélgica: já que o estrangeiro e o autóctone poderiam, os dois, gozar de direitos civis, suas leis também deveriam ser consideradas equivalentes ${ }^{144}$. Reconhecendo a todos os homens a qualidade de sujeito de direito, se deveria reconhecer a aplicação recíproca dos direitos nacionais de cada um. Em outros termos, a universalidade da disciplina seria indissociável do personalismo. O católico Hector Lambrechts também salientava, dez anos mais tarde, a necessidade da ligação entre personalismo e igualdade dos seres humanos, sendo que, a igualdade desses comportaria na legitimidade das leis da sociedade de onde provinha o estrangeiro ${ }^{145}$.

\section{A nova soberania}

O sistema de Mancini e de Laurent caminhavam juntos uma reconsideração do conceito de soberania. O realismo, arguia Laurent, era uma falsa doutrina saída de uma má interpretação da soberania $^{146}$, que repousava em uma confusão desta com a propriedade ${ }^{147}$, que vinha notadamente ilustrada na ordem feudal com "os servos vinculados à a gleba"148. É possível encontrar este mesmo vínculo entre a ordo feudal que ligava a pessoa à terra e as teorias realistas em Mancini ${ }^{149}$. A soberania antiga era um direito, um poder, que fazia referência ao solo e formava uma espécie de propriedade. Numerosos Estados, tais como os países de Common Law, que continuaram a ser

\footnotetext{
${ }^{144}$ LAURENT, François. Avant-Projet de révision du Code civil. t. I. Op. cit., p. 24.

${ }^{145}$ Segundo Lambrechts, limitar a soberania estatal não é, portanto, um problema porque o Estado tem poder somente enquanto permanecer a serviço dos indivíduos. Nesta ótica, o indivíduo é mais importante que o Estado e esse último é criado unicamente na perspectiva do primeiro. Os Estados, consequentemente, são iguais porque possuem todos a mesma finalidade. Se a finalidade do Estado é o homem, um outro Estado não o pode privar de seus direitos. Por esta razão, o indivíduo possui direitos que o Estado não pode violar. Essa é, em suma, a teoria de Locke. Devido a igualdade dos seres humanos perante a Deus e a igualdade dos Estados na comunidade internacional, o Estado deveria reconhecer ao estrangeiro a mesma proteção que ele receberia em casa. Vide, LAMBRECHTS, Hector. Les bases philosophiques du droit international privé. Revue néo-scolastique, VIII (1895), p. 425.

${ }^{146}$ LAURENT, François. Droit civil international. t. II. Op. cit., p. 229.

${ }^{147}$ LAURENT, François. Droit civil international. t. I. Op. cit., p. 527.

148 Idem, p. 37.

${ }^{149}$ MANCINI, Pasquale Stanislao. De l'utilité de rendre obligatoire, pour tous les États, sous la forme d'un ou de plusieurs traités internationaux, un certain nombre de règles générales du Droit international privé pour assurer la décision uniforme des conflits entre les différentes législations civiles et criminelles. Op. cit., pp. 222 et s.
} 
ligados a uma noção de soberania mais exclusiva e para os quais todos os estatutos eram reais, eram qualificados como "bárbaros"150.

A nova ordem, abolindo a feudalidade, inaugurava uma nova forma de soberania que, segundo Laurent, somente poderia levar à personalidade das leis. A soberania moderna, dever e missão, tinha em consideração o indivíduo ${ }^{151}$ e tinha missões bem mais elevadas, como a educação $^{152}$. As leis que emanavam da Nação eram, portanto, chamadas a dar prioridade ao indivíduo e não aos bens, que, segundo Laurent, na civilização moderna eram importantes somente à medida que teriam alguma relação com o indivíduo. As riquezas seriam simples instrumento ao serviço do indivíduo. Desde então, a nova soberania do Estado não tinha mais interesse em resolver questões puramente privadas. A terra se tornava o acessório do indivíduo, não mais o indivíduo da terra $^{153}$.

A construção da soberania acerca do indivíduo se devia, conforme Laurent, ao maior valor concedido à Pessoa, a quem se queria reconhecer direitos imprescritíveis. O personalismo era, portanto, intimamente fundamentado nos valores da Revolução francesa, indissociavelmente ligado ao liberalismo filosófico, tais como a abolição da feudalidade e os direitos imprescritíveis do ser humano ${ }^{154}$.

\section{OS DESTINATÁRIOS Do Direito InTERnaCiOnal Privado}

Escrevendo seu Droit civil international e os princípios de direito internacional privado de seu Avant-Projet de révision du Code civil, Laurent se dirigia a três atores: a diplomacia, a doutrina e o legislador.

\section{A Diplomacia}

Seria uma utopia esperar que a diplomacia se ocupasse de uma questão de moral universal? ${ }^{155}$

\footnotetext{
${ }^{150}$ LAURENT, François. Droit civil international. t. I. Op. cit., p. 25.

${ }^{151}$ LAURENT, François. Droit civil international. t. II. Op. cit., p. 133.

${ }^{152}$ LAURENT, François. Droit civil international. t. I. Op. cit., p. 549.

${ }^{153}$ Idem, p. 271.

${ }^{154}$ Idem, p. 42.

${ }^{155}$ F. Laurent a G. Rolin-Jaecquemyns, em LAURENT, François. Droit civil international. t. VIII. Op. cit., p. 4. 
Inicialmente o Droit civil international seria uma obra voltada à diplomacia. O objetivo de Laurent era encorajar a assinatura de tratados nos quais desejava ver sua opinião consagrada ${ }^{156}$. O Droit civil international era, portanto, um apelo para a celebração de tratados de direito internacional privado entre os Estados. Embora absolutamente necessária, a adoção de tratados internacionais em matéria de direito internacional foi adiada pela relutância da diplomacia.

Infelizmente, em 1881, a proposta de Mancini no que concerne a celebração de um tratado internacional foi rejeitada pelo primeiro-ministro belga Hubert Frère-Orban, que assim afirmava:

\begin{abstract}
A Analisei atentamente o memorandum do sr. Mancini. Mas, malgrado meu desejo de agradar o ministro dos negócios estrangeiros da Itália, não vejo a possibilidade de uma negociação entre os nossos dois países sobre a matéria delicada que se trata de unificar. Naturalmente, só se podia falar na condição dos estrangeiros do ponto de vista do direito civil e não a sua condição do ponto de vista do direito penal, nem do direito político. Em matéria de direito civil, contudo, o governo belga está determinado, como as leis o aprovam, a não fazer alguma distinção entre belgas e estrangeiros; princípios mais amplos vão ser adotados e, isso, sem que haja reciprocidade, por ocasião de uma revisão iminente do código civil. ${ }^{157}$
\end{abstract}

Frère-Orban não via utilidade em um acordo internacional deste tipo, acrescentando que o estatuto pessoal era já aplicado em matéria de estado, que a regra locus regit actum era já aplicada e que o direito de aubana tinha sido abolido. Ele pediu a Mancini, ao contrário, para indicar as disposições do Código civil belga prejudiciais aos estrangeiros que seria necessário modificar. Mancini contestou dizendo que Frère-Orban não teria entendido as intenções que o levaram a fazer o pedido, ou seja, que não desejava alterar as legislações nacionais, mas sim fazer com que as mesmas celebrassem acordos internacionais com o objetivo de adotar um tratamento comum a questões de direito privado ${ }^{158}$.

\title{
A doutrina
}

$\mathrm{Na}$ espera de realizar este ideal de conciliação, competia à doutrina preencher a lacuna ${ }^{159}$. Para Laurent, a doutrina preparava o trabalho diplomático. A esse respeito, ele tinha muita esperança

\footnotetext{
${ }^{156}$ LAURENT, François. Droit civil international. t. I. Op. cit., p. 21.

157 Archivio dell'Istituto per la storia del Risorgimento italiano, Fondo Mancini, n 645/2(16), "Négociations diplomatiques du gouvernement italien pour une codification conventionnelle du droit international privé", Memoriale de Mancini, Roma, Settembre 1882, p. 10.

158 Archivio dell'Istituto per la storia del Risorgimento italiano, Fondo Mancini, n 645/2(16), "Négociations diplomatiques du gouvernement italien pour une codification conventionnelle du droit international privé", Memoriale de Mancini, Roma, Settembre 1882, p. 11.

${ }^{159}$ LAURENT, François. Droit civil international. t. V. Op. cit., p. 276.
} 
no Institut de Droit international, a fim de que esse estabelecesse por meio da conciliação científica as regras comuns a todas as nações em matéria de conflito de leis ${ }^{160}$, que posteriormente poderiam ser adotadas pela diplomacia. A ciência do direito se tornava, portanto, neste âmbito, um órgão da justiça eterna formulando o justo e o injusto, e inspirando a lei. Laurent afirmava que as ideias poderiam influenciar o direito, como teria sido o caso da jurisprudência espanhola, que se baseava em Savigny ${ }^{161}$.

Na defesa de seu sistema, Laurent deveria fazer face às grande dissenções que reinavam no seio da doutrina. Na ausência de um legislador e de um tribunal internacional, a ciência se dividia em diferentes correntes que colocavam em risco o universalismo da matéria. O personalismo, de fato, mesmo se conhecia um sucesso crescente, estava longe de ser a opinião majoritária. Naquele momento a doutrina não poderia, portanto, ser considerada enquanto tal uma fonte de direito internacional ${ }^{162}$. Quando os intérpretes não encontravam um acordo, a teoria não era suficiente para resolver as questões ${ }^{163}$. Desde então, com o Droit civil international, Laurent tinha por objetivo reunir as opiniões divididas ${ }^{164}$. Para isso, se voltava prioritariamente aos jurisconsultos especialistas da matéria com a finalidade de fazê-los convergir ao personalismo nacionalista. $\mathrm{O}$ fato de as teorias na época serem essencialmente contraditórias não o desencorajou: mesmo rejeitando uma tendência que considerava materialista, recusou-se a concluir que o direito internacional privado não existia. Pareceria, ao contrário, que uma doutrina unívoca poderia servir de fonte ${ }^{165}$. Era um ramo do direito, no momento em que Laurent escrevia, somente embrionário.

\section{O legislador}

O Droit civil international, visto como complemento do Avant-Projet de révision du Code civil $^{166}$, teria por terceiro objetivo convencer o legislador belga da legitimidade dos princípios adotados e de o fazer adotar as regras unificadas na matéria, ao menos em nível nacional. O AvantProjet se dava por missão se adaptar aos avanços da ciência do direito internacional privado, com a

\footnotetext{
${ }^{160}$ Idem, p. 80.

${ }^{161}$ LAURENT, François. Droit civil international. t. VI. Op. cit., p. 284.

${ }^{162}$ LAURENT, François. Droit civil international. t. I. Op. cit., p. 79

${ }^{163}$ LAURENT, François. Droit civil international. t. II. Op. cit., p. 20

${ }^{164}$ Idem, p. 230.

${ }^{165}$ Idem, p. 82.

${ }^{166}$ LAURENT, François. Droit civil international. t. I. Op. cit., p. VIII.
} 
finalidade de estabelecer uma legislação imobilizada ${ }^{167}$ : "Meu objetivo é chegar a princípios sobre os quais se possa fundar a comunidade de direito, o ideal da nossa ciência". ${ }^{168}$

Uma série de princípios foram consagrados por Laurent, mas, mesmo assim, certos conflitos eram considerados por ele como irresolvíveis e que somente poderiam ser regulados por meio de acordos entre as diferentes nações. Caberia aos juristas, então, a missão de preparar a tarefa dos diplomatas propondo todo um rol de princípios que deveriam ser comuns a todos os Estados. Eles não tinham, no entanto, nenhum tipo de poder de criação do direito. Os órgãos da nação é que deveriam se expressar. O legislador, "artesão do progresso" ${ }^{169}$, por meio das leis; e o diplomata, por meio da adoção dos tratados, lhe darão seu caráter obrigatório: "Meu objetivo não é somente expor a legislação existente, eu gostaria de chegar a uma reforma do direito, que poderá ser admitida por todas as nações civilizadas, realizando a comunidade de direito e a unidade do gênero humano nas relações de interesse privado, o que é o objeto ideal da ciência do direito internacional privado". ${ }^{170}$

\section{CONSIDERAÇÕES FINAIS}

A segunda metade do XIX século testemunha uma verdadeira reflexão internacional em matéria de conflito de leis. Os jurisconsultos interessados no direito internacional formaram uma rede europeia e dialogaram por meio de artigos e de tratados, adotando por vezes pontos de vista muito críticos sobre as contribuições de seus confrades. O otimismo e o idealismo, em Mancini como em Laurent, encorajavam o reconhecimento de uma comunidade de direito mundial. O internacionalismo característico da "Belle époque" belga ${ }^{171}$ encontrava ainda uma ilustração não obra de Laurent. De modo geral, a doutrina por ele elaborada tinha por objetivo incentivar os valores das Luzes e da Revolução. Nesta perspectiva, não é surpreendente o fato de que várias nações tenham adotado o personalismo de Mancini nas suas codificações, já que esse último cristalizava essa corrente de pensamento em voga no final do XIX século, a meio caminho entre o nacionalismo e o liberalismo, inspirado nas Luzes francesas e no Iluminismo napolitano.

\footnotetext{
${ }^{167}$ LAURENT, François. Avant-Projet de révision du Code civil. t. I. Op. cit., p. 28.

${ }^{168}$ LAURENT, François. Droit civil international. t. III. Op. cit., p. 482.

${ }^{169}$ LAURENT, François. Avant-Projet de révision du Code civil. t. I. Op. cit., p. IV.

${ }^{170}$ LAURENT, François. Droit civil international. t. III. Op. cit., p. 378.

${ }^{171}$ LAQUA, Daniel. The age of internationalism and Belgium. 1880-1930. Peace, progress and prestige. Manchester: Manchester University Press, 2013, pp. 9 e ss.
}

DOI: https://doi.org/10.46699/rduno.v3i4.6031 | Edição Vol. 3, Núm. 4, 2020. 
Tratava-se, no entanto, de um nacionalismo racionalista e inclusivo, marcado por um certo voluntarismo, a priori inofensivo, à medida em que combinava com a liberdade de emigração e de direitos humanos inalienáveis. A comunidade de direito, muito popular no XIX século, foi colocada em causa por jurisconsultos tais como Étienne Bartin ${ }^{172}$. Malgrado os desejos dos universalistas, o direito internacional privado permanecia bastante nacional ${ }^{173}$.

O Droit civil international era de fato um trabalho particular, que não corresponde à opinião que habitualmente paira sobre o trabalho do civilista no XIX século. E não sem razão, o jurisconsulto, já liberado do Código no âmbito de uma doutrina prescritiva, tinha toda a liberdade de mobilizar por sua própria conta o direito natural que, como temos visto, nunca tinha desaparecido. A teoria do conflito de leis de Laurent, como aquela de Mancini, encontrava-se imbuída de um espírito jusnaturalista que vinha seriamente a mitigar o positivismo estatal característico da doutrina civilista do XIX século. Este fenômeno permite a Jean-Louis Halpérin afirmar, a propósito de François Laurent, que "sua doutrina prescritiva era antípoda ao positivismo"174.

\section{REFERÊNCIAS}

ANCEL, Bertrand. Élements d'histoire du droit international privé. Paris: Panthéon-Assas, 2017.

ASSER, Tobias M. C.; RIVIER, Alphonse. Éléments de droit international privé ou du conflit des lois. Paris: Rousseau, 1884.

BARTOLINI, Giulio. Le leggi razziali e la dottrina italiana di diritto internazionale. In: RESTA, Giorgio; ZENO-ZENCOVICH, Vincenzo (a cura di). Leggi Razziali, Passato/Presente. Roma: Roma TrePress, 2015.

BROCHER, Charles Antoine. Étude sur le traité de droit civil international publié par M. Laurent et sur les principes fondamentaux du droit international privé. Revue de droit international et de législation comparée, 1881, p. 533.

BRUYÈRE, Elisabeth. Principes, esprit et controverses: l'avant-projet de code civil de François Laurent ou l'œuvre séditieuse d'un libre-penseur. Tese de doutorado apresentada na Universiteit Gent (Bélgica), 2019.

CATELLANI, Enrico L. Il diritto internazionale privato e i suoi recenti progressi. t. I. Torino: Unione tipografico-editrice, 1883.

172 ANCEL, Bertrand. Élements d'histoire du droit international privé. Op. cit., p. 507.

173 SIEHR, Kurt. Private international law, history of. In: BASEDOW, Jürgen; RÜHL, Giesela; FERRARI, Franco; DE MIGUEL ASENSIO, Pedro (dir.). Encyclopedia of Private International Law. Cheltenham: Elgar, 2017, pp. 13911401.

${ }^{174}$ HALPÉRIN, Jean-Louis. Entre nationalisme juridique et communauté de droit. Op. cit., p. 94.

DOI: https://doi.org/10.46699/rduno.v3i4.6031 | Edição Vol. 3, Núm. 4, 2020. 
COUPAIN, Nicolas. L'expulsion des étrangers en Belgique (1830-1914). Revue belge d'histoire contemporaine, XXXIII (2003), p. 7.

DE ROBBIO, Antonella; GIACOMAZZI, Silvia. Storia e memoria di una biblioteca salvata: Il progetto di recupero e valorizzazione del fondo Enrico Catellani all'Università di Padova, Biblioteche oggi, 29 (2011), pp. 47-65.

DE RYCKE, Wouter. The Legal Construction of Peace before 1870. Networks and Arguments. Tese de doutorado em elaboração na Vrije Universiteit de Bruxelas (VUB) (Bélgica).

ESPERSON, Pietro. Il principio di nazionalità, applicato alle relazioni civili internazionali. Pavia: Fusi, 1868.

ESPERSON, Pietro. Movimento giuridico in Italia e nel Belgio sul Diritto internazionale privato. Firenze: Civelli, 1870.

FALLON, Marc. L'application de l'article 3, alinéa 3, du Code civil par la jurisprudence belge du xix $^{\mathbf{e}}$ siècle. In: ERAUW, Johan; BOUCKAERT, Boudewijn; BOCKEN, Hubert; GAUS, Helmut;

STORME, Marcel (dir.). Liber Memorialis François Laurent. Bruxelles: Scientia 1989.

FIORE, Pasquale. Diritto internazionale privato, o principii per risolvere i conflitti tra le legislazioni diverse in matteria di diritto civile e commerciale, Firenze: Le Monnier, 1869.

HALPÉRIN, Jean-Louis. Entre nationalisme juridique et communauté de droit. Paris: PUF.

JESSURUN D'OLIVEIRA, Hans Ulrich. Principe de nationalité et droit de nationalité, Notes de lecture au sujet du Droit civil international de François Laurent. In: ERAUW, Johan;

BOUCKAERT, Boudewijn; BOCKEN, Hubert; GAUS, Helmut; STORME, Marcel (dir.). Liber Memorialis François Laurent. Bruxelles: Story-Scientia, 1989.

KOSKENNIEMI, Martti. The gentle civilizer of nations. The rise and fall of International Law 1870-1960. Cambridge: Cambridge University Press, 2001.

LAMBRECHTS, Hector. Les bases philosophiques du droit international privé. Revue néoscolastique, VIII (1895), p. 425.

LAQUA, Daniel. The Age of Internationalism and Belgium. 1880-1930. Peace, Progress and Prestige. Manchester: Manchester University Press, 2013.

LAURENT, François. Avant-Projet de révision du code civil. 6 t. Bruxelles: Bruylant-Christophe, 1882-1885.

LAURENT, François. Des doctrines nouvelles sur le droit des gens. La libre Recherche, XVIII (1860), p. 342.

DOI: https://doi.org/10.46699/rduno.v3i4.6031 | Edição Vol. 3, Núm. 4, 2020. 
LAURENT, François. Droit civil international. 8 t. Bruxelles: Bruylant-Christophe, 1880-1881.

LAURENT, François. Études sur l'histoire de l'humanité. La philosophie de l'Histoire. t. XVIII. Bruxelles: Lacroix, 1870.

LAURENT, François. Exposé et critique des principes généraux en matière de statuts réels et personnels d'après le droit français. Revue de droit international et de législation comparée, 1869 , pp. $244-272$.

LAURENT, François. Carta a Augusto Pierantoni, 29 fevereiro 1879. Archivio dell'Istituto per la storia del Risogimento italiano, $768 \mathrm{n}^{\circ} 120$ (1).

LAURENT, François. Carta a Pasquale S. Mancini, 1879, Archivio dell'Istituto per la storia del Risorgimento Italiano, 986/26 (2).

LAURENT, François. Principes de droit civil français. t. I. Bruxelles: Bruylant-Christophe, 1869.

LOCHAK, Danièle. L'étranger dans le Code civil. In: BLOCH, Pascale; DUVERT, Cyrylle; SAUPHANOR-BROUILLAUD, Natacha. Différenciation et indifférenciation des personnes dans le code civil. Paris: Economica, 2006.

MANCINI, Pasquale Stanislao. De l'utilité de rendre obligatoire, pour tous les États, sous la forme d'un ou de plusieurs traités internationaux, un certain nombre de règles générales du Droit international privé pour assurer la décision uniforme des conflits entre les différentes législations civiles et criminelles. Journal de droit international, 1874, p. 224.

MANCINI, Pasquale Stanislao. Négociations diplomatiques du gouvernement italien pour une codification conventionnelle du droit international privé. Mémoire. Archivio dell'Istituto per la storia del Risorgimento italiano. Fondo Mancini, n 645/2(16). Roma, setembro 1882, p. 10.

MURA, Eloisa. All'ombra di Mancini. La disciplina internazionalistica in Italia ai suoi albori. Pisa: ETS, p. 139.

PICARD, Edmond; D'HOFFSCHMIDT, Napoléon. Pandectes Belges: encyclopédie de législation, de doctrine et de jurisprudence belges. t. 67. Bruxelles: Larcier, 1901.

PIERANTONI, Augusto. Storia del diritto internazionale nel secolo XIX. Napoli: Marghieri, 1876.AA. Révision du Code civil belge. Revue de droit international et de législation comparée, 1886, p. 492.

ROLIN-JACQUEMYNS, Gustave. Les principes philosophiques du droit international. Revue de droit international et de législation comparée, XVII (1886), p. 60.

SIEHR, Kurt. Private international law, history of. In: BASEDOW, Jürgen; RÜHL, Giesela; FERRARI, Franco; DE MIGUEL ASENSIO, Pedro (dir.). Encyclopedia of Private International Law. Cheltenham: Elgar, 2017. 
WEISS, André. Manuel de droit international privé. 6ª ed. Paris: Larose, 1909.

TEICHMANN, Albert. Étude sur l'affaire de Bauffremont, envisagée au point de vue des législations française et allemande. Bâle: Meyri’s Buchhandlung, 1876.

VANKEERSBILCK, Maarten. Justitie in de steigers: gerechtelijke hervormingen in belgië, De moeizame weg naar het gerechtelijk wetboek. Tese de doutorado apresentada na Universiteit Gent (Bélgica), 2019. 